\title{
The Relation Between the Metopic Suture Persistence and Frontal Sinus Volume and Olfactory Fossa Depth: A Reliability Study with Semiautomatic Volume Measurement
}

\section{Persistan Metopik Sütür ile Frontal Sinüs Hacmi ve Olfaktör Fossa Derinliği Arasındaki İlişki: Semi-otomatik Volüm Ölçümü Çalışması}

\author{
(D) Basak ATALAY, (D) Mehmet Bilgin ESER
}

Istanbul Medeniyet University Faculty of Medicine, Department of Radiology, Istanbul, Turkey

\begin{abstract}
Objective: This study aims to investigate the relationship of the persistence of metopic suture (PMS), frontal sinus volume (FSV), and olfactory fossa depth (OFD).

Methods: Tomography scans of 1,603 patients aged 18-65 years were evaluated for the presence of PMS. In the study, 74 PMS cases and 74 controls were included. The appearance of each individual's frontal sinus was classified as aplasia, hypoplasia, or normal. Two observers independently measured the lateral lamella length (LLL), OFD, and FSV. Interobserver agreement was evaluated with the intraclass correlation coefficient (ICC) and Cohen's kappa coefficient $(\kappa)$

Results: The prevalence of PMS was found to be 4.99\% [95\% confidence interval (Cl): 4.03-6.17]. The PMS group had five times higher hypoplasia/aplasia than the controls $(52.70 \%, 95 \% \mathrm{CI}$ : $41.48-63.66$ and $10.81 \%$, 95\% CI: 5.58-19.91, respectively; p<0.001). An "almost perfect" agreement was detected among observers for the frontal sinus appearance classification: $\kappa=0.807, p<0.001$. The ICC of continuous measurements for OFD, LLL, and FSV, respectively, presented "excellent" reliability: 0.956, 0.958, and 0.981, with $\mathrm{p}<0.001$ for each. LLL was shorter, OFD was shallower, and FSV was smaller in the PMS group than the control group $(\mathrm{p}<0.001)$. There was a moderate positive correlation between OFD, LLL, and FSV ( $\mathrm{r}=0.306, \mathrm{r}=0.302)$.

Conclusions: This study interprets that the presence of PMS is related frontal sinus development and volume. With PMS, a smaller FS, shorter lateral lamella, and shallower olfactory fossa may be expected.

Keywords: Metopic suture, computed tomography, 3D imaging, frontal sinus, olfactory groove
\end{abstract}

Received: 09 September 2021

Accepted: 30 October 2021

Online First: 19 November 2021

Corresponding Author

M. B. Eser

Istanbul Medeniyet University Faculty of Medicine, Department of

Radiology, Istanbul, Turkey

bilgineser@gmail.com

ORCID: 0000-0003-2490-9449

Öz

Amaç: Bu çalışma, persistan metopik sütür (PMS) ile olfaktör fossa derinliği (OFD), ve frontal sinüs volümü (FSV) arasındaki ilişkiyi araştırmayı amaçlamaktadır.

Yöntemler: Yaşları 18-65 arasında değişen 1.603 hastanın tomografileri PMS varlığı açısından değerlendirildi. Yetmiş dört PMS olgusu ve 74 kontrol çalışmaya dahil edildi. Her bireyin frontal sinüs görünümü aplazi, hipoplazi veya normal olarak sınıflandırıldı. Lateral lamella uzunluğu (LLU), OFD ve FSV ölçümleri iki gözlemci tarafından bağımsız olarak yapıldı. Gözlemciler arası uyum değerlendirilirken, sürekli değişkenler için sınıf içi korelasyon katsayısı (ICC) ve Cohen's kappa katsayısı (к) kullanıldı.

Bulgular: PMS prevalansı \%4,99 [güven aralığı (GA) \%95: 4,03-6,17] olarak bulundu. Hipoplazi/aplazi, PMS grubunda kontrol grubuna göre beş kat daha fazlaydı (sırasıyla \%52,70; GA \%95: 41,48-63,66 ve \%10,81; GA

Cite as: Atalay B, Eser MB. The Relation Between the Metopic Suture Persistence and Frontal Sinus Volume and Olfactory Fossa Depth: A Reliability Study with Semiautomatic Volume Measurement. Medeni Med J 2021;36:287-293

${ }^{\circledR}$ Copyright 2021 by the Istanbul Medeniyet University / Medeniyet Medical Journal published by Galenos Publishing House.

Licenced by Creative Commons Attribution-NonCommercial 4.0 International (CC BY-NC 4.0) 
\%95: 5,58-19,91, p<0,001). Frontal sinüs görünüm sınıflandırması için gözlemciler arasında "mükemmel" bir uyum tespit edildi: $\kappa=0,807$, $p<0,001$. OFD, LLU ve FSV için ICC "mükemmel" güvenilirlik sundu: Her biri için sırasıyla 0,956, 0,958 ve 0,981 ve $p<0,001$. PMS grubunda, LLU daha kısaydı, OFD daha sığdı ve FSV, kontrol grubuna göre daha küçüktü (her biri için $\mathrm{p}<0,001)$. OFD, LLU ve FSV arasında orta derecede pozitif korelasyon vardı $(\mathrm{r}=0,306, \mathrm{r}=0,302)$.

Sonuçlar: Bu çalışmanın sonucunda, PMS'nin frontal sinüs gelişimi ve volümü ile ilişkili olduğu bulunmuştur. PMS varlığında daha küçük bir FS, daha kısa lateral lamella ve daha az derin olfaktör fossa beklenebilir.

Anahtar kelimeler: Metopik sütür, bilgisayarlı tomografi, 3D görüntüleme, frontal sinüs, olfaktör oluk

\section{INTRODUCTION}

The metopic suture (MS) is a cranial suture that starts at the anterior fontanelle and extends to the nasion. MS often closes in early childhood. In the event of nonclosure, a variation known as "persistent MS (PMS)" is used ${ }^{1,2}$. The pneumatization of paranasal sinuses (PNS) might vary depending on anatomic variations. Although PMS is an anatomical variation, the suture may be misdiagnosed as a frontal bone fracture ${ }^{1.3}$. It is possible that being aware of this persistence will help prevent misdiagnosis. To evaluate pneumatization variations of PNS and the relation with adjacent anatomical structures, computed tomography (CT) is the most used reference imaging technique ${ }^{4-6}$.

As Keros ${ }^{7}$ described previously, olfactory fossa depth (OFD) and lateral lamella length (LLL) are relevant, and a deeper OF increases the risk of iatrogenic injury. A preoperative evaluation of this area is necessary to avoid damage and to abate potential complications, such as cerebrospinal fluid leakage, epistaxis, and hematoma.

We hypothesized that the OFD, LLL, and frontal sinus volume (FSV) of individuals with PMS would differ from those without PMS since OFD, LLL, and FSV development may be negatively correlated with PMS.

\section{MATERIALS and METHODS}

Istanbul Medeniyet University Goztepe Training and Research Hospital Clinical Research Ethics Committee approved this retrospective case-control study (decision no: 2019/0133, date: 27.03.2019), and the informed patient consent was waived by the Institutional Review Board. The STROBE statement was followed ${ }^{8}$.

Brain CT images from the archive taken between January and May 2019 were re-evaluated in this retrospective study. The majority of the CTs were for head trauma, stroke, and headache. The frontal sinuses become visible radiologically at the age of 6 , and they grow to adult sizes in adolescence 5 . As a result, an age range of 18-65 years was covered. A total of 1,603 Caucasian patients were screened; those with PMS were included in the case group, and the control group was formed by a random selection method from screened patients.

The inclusion criteria for the case group were as follows: presence of CT images with a cross-sectional thickness of $1.25 \mathrm{~mm}$ in the bone algorithm and complete imaging of the PNS; and presence of consistent frontal MS. The control group was formed from the participants who met the same criteria but did not have MS.

The exclusion criteria for both groups were as follows: inadequate CT imaging of the LL and OF; and changed sinus anatomy as a result of trauma or other reasons (infections, polyposis, tumor, remodeling of bone). There were 74 PMS cases and 74 controls in the study.

\section{Computed Tomography Imaging}

All the cranial CT scans (GE Optima CT660 GE Healthcare, Milwaukee, WI) were performed at our hospital. The scanning range included from the vertex to the atlas masses, and data were collected with a GE system equipped with a $512 \times 512$ matrix detector. The slice thickness was $1.25 \mathrm{~mm}$.

Frontal Sinus Volume Measurement Protocol and Frontal Sinus Appearance Classification

Slicer software, version 4.10 .2 (https://www.slicer.org) was used for volumetric measurements (Figure 1). The axial images with bone window were used, and measurements were made independently using the semiautomatic "segment editor" module and "level-tracing" application. After segmentation, segment volume was calculated using the "segment statistics" module. Each observer measured the FSV of both groups independently and noted the values in cubic centimeter. Cases where the FSs could not be measured volumetrically were accepted as aplasia.

LLL was measured as the lateral border of the cribriform plate (Figure 2) ${ }^{7}$. Two observers for both sides measured the LLL and OFD values, and the mean values were calculated. Using the guidelines that Guerram et al. ${ }^{9}$ recommended, the FSs were classified as aplasia, hypoplasia, or normal. 


\section{Statistical Analysis}

The Kolmogorov-Smirnov test showed normal data distributions for OFD and LLL, but not for FSV. To compare OFD and LLL, t-test was used. The FSV values were compared using Mann-Whitney $\mathrm{U}$ test. In each group, the right and left measurements paired. Spearman's correlation was performed to understand the relation between FSV and OFD and LLL. Interobserver agreement was evaluated with the intraclass correlation coefficient (ICC) for continuous variables, and with Cohen's kappa coefficient $(\kappa)$ for ordinal variables (FS appearance classification). ICC values less than 0.5 are indicative of poor reliability, values between 0.5 and 0.75 indicate moderate reliability, values between 0.75 and 0.9 indicate good reliability, and values greater than 0.90 indicate excellent reliability. Kappa values $\leq 0$ were considered as having no agreement, $0.01-0.20$ as none to slight, 0.21-0.40 as fair, $0.41-0.60$ as moderate, $0.61-0.80$ as substantial, and $0.81-1.00$ as almost perfect agreement. OFD and LLL subgroup analyses were performed with a t-test and analysis of variance. The MS group contained three subgroups (normal, hypoplasia, and aplasia); the control group included two subgroups (normal and hypoplasia). FSV subgroup analysis for MSs was performed using the Kruskal-Wallis and Mann-Whitney $U$ tests for the control group. Receiver operating characteristic curve analyses were used to calculate the cutoff value between hypoplastic and normal appearance FSVs. The data were analyzed using IBM SPSS Statistics for Mac OS X (Version 22.0., IBM Corp., Armonk, NY). The level of statistical significance was accepted at $\mathrm{p}<0.05$. Power analysis was performed using $G^{*}$ Power 3.1.9.3 for Mac Os X (http:// www.gpower.hhu.de/) and analysis was done post-hoc. The standardized effect size was $d=0.90$, alpha $=5 \%$, the retrospective power value was $99.95 \%$.

\section{RESULTS}

\section{Demographics}

Mean age was $46.88 \pm 13.07$ for the PMS group and $40.05 \pm 14.62$ for the controls. Demographic distribution is summarized in Table 1. This study found PMS prevalence to be $4.99 \%$ [95\% confidence interval $(\mathrm{CI})$ : 4.03-6.17] for
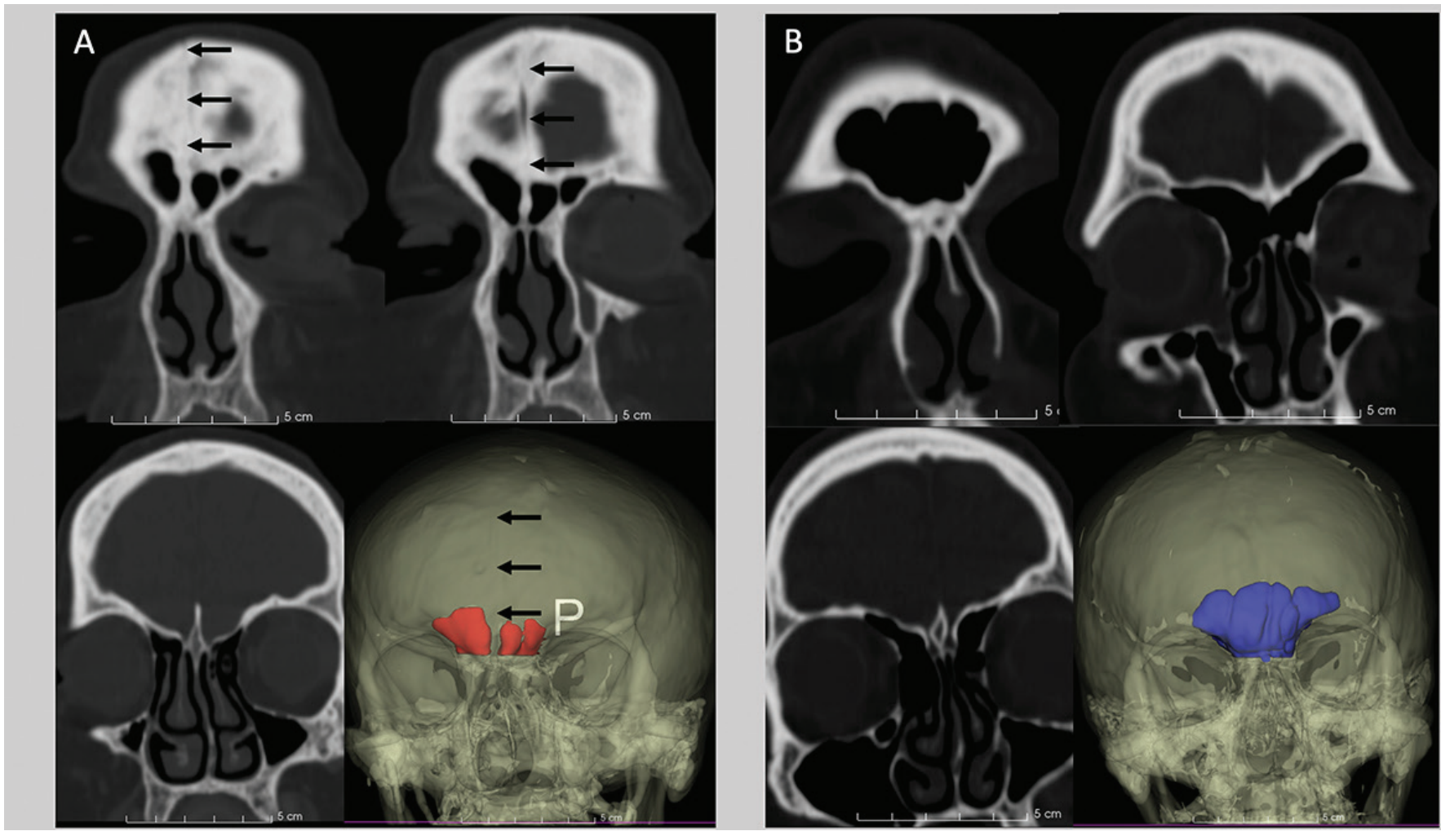

Figure 1. Coronal reformatted CT images and 3D reconstructed images (A and B). The PMS is exhibited with black arrows on the midline (A). The FSV appears smaller in the PMS patient (A).

FSV: Frontal sinus volume, CT: Computed tomography, PMS: Persistence of metopic suture 
the screened population (female: $45 / 793,5.67 \%, 95 \% \mathrm{Cl}$ : 4.27-7.51 and male: 35/810, 4.32\%, 95\% Cl: 3.12-5.95).

Interobserver Agreement for Frontal Sinus Appearance and Interobserver Reliability for Measurements

In the FS appearance classification, an "almost perfect" agreement was detected between observers; $\kappa=0.807, \mathrm{p}<0.001$. ICC of continuous measures presented "excellent" reliability for OFD, LLL, and FSV respectively: $0.956,0.958$, and 0.981 , and $p<0.001$ for each.

Frontal Sinus Volume, Lateral Lamella Length, and Olfactory Fossa Depth

In the PMS group, hypoplasia/aplasia prevalence $(52.70 \%$, 95\% CI: 41.48-63.66) was found to be approximately fivefold higher than that of controls $(10.81 \%$, 95\% CI: 5.58-19.91). Especially in the female PMS group, the difference was more proclaimed, and hypoplasia/ aplasia prevalence was higher than the male PMS group (63.41\%, 95\% Cl: $48.12-76.41$, and $39.39 \%$, 95\% CI: $24.68-$ 56.32, respectively; $\mathrm{p}=0.025$ ).

Mean values for all individuals were comparatively evaluated; a significant difference was observed in OFD, LLL, and FSV between the PMS and the control group. Outcome measures for both groups are summarized in Table 2.

\section{Subgroup Analysis Based on Frontal Sinus} Appearance

The subgroups formed according to FS appearance were analyzed; aplasia was not detected in the control group. The volumetric evaluation of the FSs shows that the volume of FSs of the PMS group was lower than the

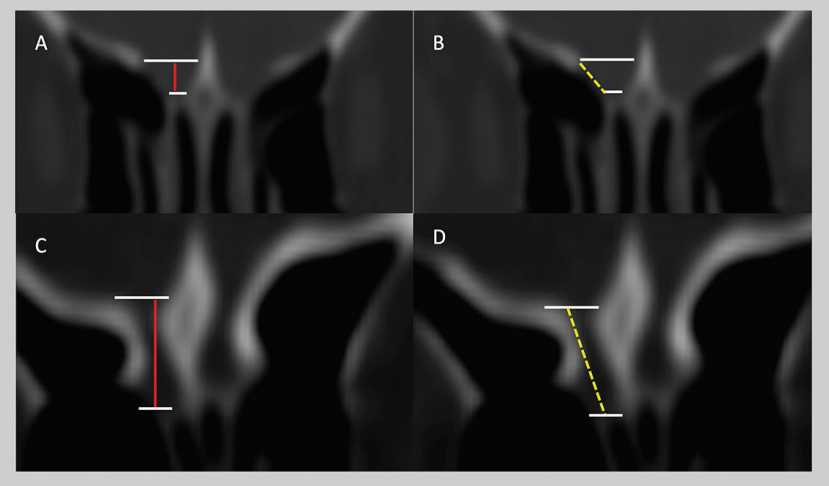

Figure 2. Coronal reformatted CT images. The OFD is less, and the LLL is shorter in the PMS patient (A, B). The OFD is deeper and the LLL is longer in the control group (C, D).

LLL: Lateral lamella length, OFD: Olfactory fossa, PMS: Persistence of metopic suture, CT: Computed tomography

\begin{tabular}{|c|c|c|c|c|c|c|c|c|}
\hline \multirow{2}{*}{$\begin{array}{l}\text { Metopic } \\
\text { suture }\end{array}$} & \multirow{2}{*}{ Gender } & \multirow{2}{*}{$\begin{array}{l}\text { Frequency } \\
\text { n (\%) }\end{array}$} & \multicolumn{2}{|l|}{ OFD (mm) } & \multicolumn{2}{|l|}{ LLL (mm) } & \multicolumn{2}{|l|}{ FSV $\left(\mathrm{cm}^{3}\right)$} \\
\hline & & & Mean \pm SD & p-value & Mean \pm SD & p-value & Mean \pm SD & p-value \\
\hline \multirow{2}{*}{ Metopic } & Female & $41(55.4)$ & $5.08 \pm 1.78$ & \multirow{2}{*}{0.186} & $5.83 \pm 1.68$ & \multirow{2}{*}{0.802} & $4.45 \pm 3.05$ & \multirow{2}{*}{$0.008^{*}$} \\
\hline & Male & 33 (44.6) & $4.58 \pm 1.28$ & & $5.74 \pm 1.26$ & & $7.64 \pm 5.83$ & \\
\hline \multirow{2}{*}{ Control } & Female & $41(55.4)$ & $6.31 \pm 1.77$ & \multirow{2}{*}{0.919} & $7.11 \pm 1.65$ & \multirow{2}{*}{0.548} & $8.99 \pm 5.36$ & \multirow{2}{*}{$0.021^{*}$} \\
\hline & Male & 33 (44.6) & $6.35 \pm 1.55$ & & $7.35 \pm 1.71$ & & $12.58 \pm 7.12$ & \\
\hline
\end{tabular}

\begin{tabular}{|c|c|c|c|c|c|}
\hline & Metopic suture & $\mathbf{N}$ & Mean & SD & $\mathbf{p}$ \\
\hline \multirow{2}{*}{ OFD } & Metopic & 74 & 4.86 & 1.59 & \multirow{2}{*}{$<0.001^{*}$} \\
\hline & Control & 74 & 6.32 & 1.66 & \\
\hline \multirow{2}{*}{ LLL } & Metopic & 74 & 5.79 & 1.50 & \multirow{2}{*}{$<0.001^{*}$} \\
\hline & Control & 74 & 7.21 & 1.67 & \\
\hline \multirow{2}{*}{ FSV } & Metopic & 74 & 5.88 & 4.76 & \multirow{2}{*}{$<0.001^{*}$} \\
\hline & Control & 74 & 10.59 & 6.42 & \\
\hline
\end{tabular}


control group, although according to the appearance, they were classified as normal. Participants with the same subgroup (normal and hypoplasia) were compared between metopic and control groups; all measurements (OFD, LLL, and FSV) were significantly higher in the control group. Details of all subgroup analysis results are given in Figure 3.

Using with receiver-operating characteristic analysis, a cutoff value of $4.55 \mathrm{~cm}^{3}$ was found to quantitively differentiate hypoplastic and normal appearance subgroups (area under the curve $=0.99 ; 95 \%$ confidence interval: $\quad 0.985-1.000 ; \quad \mathrm{p}<0.001$; sensitivity: $96.0 \%$; specificity: $97.9 \%)$.

\section{Correlation Between Frontal Sinus Volume and} Olfactory Fossa Depth and Lateral Lamella Length

Spearman's correlation test was applied to the case and control groups to understand the compatibility between the measurements of OFD, LLL, and FSV. For mean LLL, the Spearman rho value for correlation with OFD was 0.824 ( $\mathrm{p}<0.001)$. There was a moderate positive correlation between LLL and FSV (rho $=0.306, p<0.001$ ) and between OFD and FSV ( $r$ ho $=0.302, p<0.001$ ).

\section{DISCUSSION}

\section{Prevalence of Persistent Metopic Suture}

There was a significant difference in OFD, LLL, and FSV between the PMS and the control group ( $p<0.001)$. The development of these adjacent anatomical structures seems to be related. With the presence of PMS, a smaller FS, shorter LL, and less deep OF may be expected.

The prevalence of PMS differs among genders ${ }^{10}$. According to an X-ray analysis of the skull, PMS prevalence is $1.75 \%$, with men having a relatively higher frequency than women. In that study, most individuals with complete MS did not have the FS". In another radiographic study, Guerram et al. ${ }^{9}$ used a simple classification for FS pneumatization and reported that an absence of or a small FS was more frequent in skulls with PMS. In a more recent study using $\mathrm{CT}$ and magnetic resonance imaging together, PMS prevalence was reported to be $9.7 \%$. The study found no significant correlation between the presence of PMS and the development of the $\mathrm{FS}^{12}$. It has been suggested that this might be due to the use of the $\mathrm{X}$-ray technique. However, studies in which CT images were used did show a relation between PMS and the FS.
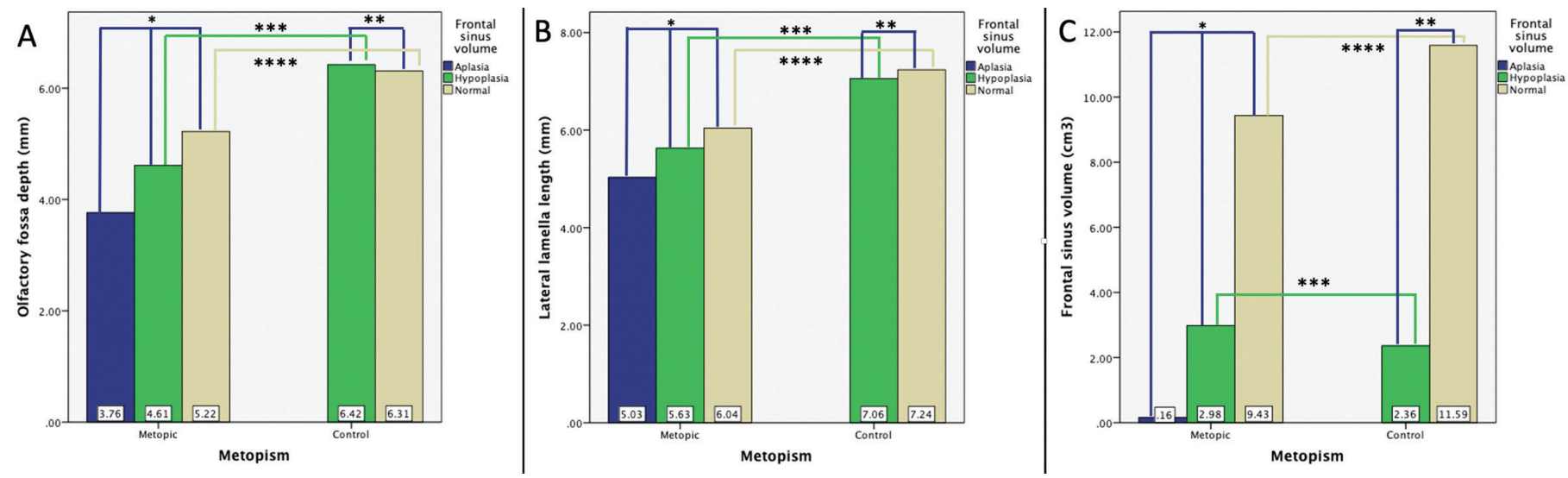

Figure 3. This diagram presents the relationship between the subgroups of the frontal sinus (aplasia, hypoplasia, and normal) with olfactory fossa (OFD) (A), lateral lamella length (LLL) (B), and frontal sinus volume (FSV) (C). Comparisons were made within groups for both the metopic and control groups and across the same subgroups.

The OFD and LLL measurements of persistence of metopic suture (PMS) patients increased from aplasia to normal appearance between the three subgroups, but this difference was not significant ( $\mathrm{A}$ : ${ }^{*} \mathrm{p}=0.059$; $\mathrm{B}$ : $\left.{ }^{*} \mathrm{p}=0.179\right)$. Similarly, there was no significant difference between the subgroups in the control group for OFD and LLL (A: ${ }^{* *} \mathrm{p}=0.861$; $B$ : $\left.{ }^{* *} \mathrm{p}=0.775\right)$. Across-group comparison of hypoplastic FS participants: individuals from the control have deeper OFD $\left(\mathrm{A}:{ }^{* * *} \mathrm{p}=0.006\right)$ and longer LLL than the PMS group (B: $\left.{ }^{* * *} \mathrm{p}=0.019\right)$. Again, this comparison was made for the FSs with normal appearance; a significant difference was found for OFD (A: $\left.{ }^{* * *} \mathrm{p}=0.002\right)$ and LLL (B: $\left.{ }^{* * * *} \mathrm{p}=0.001\right)$. FSV exhibited a significant difference between the subgroups in both the metopic group and the control group (C: ${ }^{*} \mathrm{p}<0.001$; $\left.\mathrm{C:}{ }^{* *} \mathrm{p}<0.001\right)$. Although the normal subgroup's FSV in the PMS group was less than the control group, there is no significant difference between the metopic and control groups. The FSV did not differ between the metopic and the control groups for hypoplastic and normal FS appearance participants (C: ${ }^{* * *} \mathrm{p}=0.222$ and $\left.{ }^{* * * *} \mathrm{p}=0.076\right)$ 


\section{The Relation Between PMS and OFD, LLL, and FSV}

The relationship between FSV and OFD, as well as the relationship between PMS and FSV, have been previously studied ${ }^{25,13}$. This study evaluated the relation between PMS and OFD, LLL, and FSV. The semiautomatic measurement of FSV provides a reliable quantitative evaluation for the FSV.

OFD is less deep and LLL is shorter in the PMS group. These results might be related to the presence of hypoplasia/aplasia at a higher rate in the PMS group. However, the most effective variable on OFD and LLL seems to be the presence of PMS (Figure 3). The cutoff value for FS hypoplasia was calculated as $4.55 \mathrm{~cm}^{3}$. The semiautomatic method, which we recommend, provides a volumetric quantitative evaluation for FS.

Although studies have shown that OFD increases when an FS is over-pneumatized, the effects of FSV on OFD are controversial ${ }^{5,13}$. Kayabasi et al. ${ }^{6}$ claimed that the pneumatization defects of the frontal, maxillary, and sphenoid sinuses were associated with a deeper OF and a longer LL. However, these results are inconsistent with the literature ${ }^{5.13}$. Although the evaluation of the relation between maxillary and sphenoid sinus pneumatization with OFD provides a different perspective, the developmental relation and time are different from the FS.

This study evaluated PMS association with OFD, LLL, and FSV and hypothesized the relation in the development of these adjacent anatomical structures. A significant relation was found between PMS and OFD, LLL, and FSV. These results support the hypothesis of the current study. The possible mechanism of this association is a relation in the development process.

To prevent bias, two independent observers evaluated FSV, OFD, and LLL without knowing each other's results. While the volumetric measurements provide a quantitative value for FSV, the interobserver evaluation improves the reliability of the study.

\section{Clinical Importance of Preoperative Imaging}

The use of endoscopic sinus, pituitary, and nasal septum surgeries is becoming more common ${ }^{14-16}$. Lifethreatening conditions, such as a cerebrospinal fluid leak, epistaxis, postoperative hematoma, meningitis are common complications in these surgeries ${ }^{14}$. Because of the anatomical proximity of the frontal sinus to the orbit and anterior skull base, neurosurgeons must consider this when performing supraorbital craniotomy ${ }^{17}$. Previous research has suggested that an increase in OFD may be associated to a higher risk of complications ${ }^{18}$. This study found a positive correlation between FSV and OFD. Previous studies supported these findings and reported, stating that individuals with a hyper aerated FS seem to be more prone to the risk of complication ${ }^{5,6,18}$. During the skull base surgery, the LL as the thinnest part of the skull base is a common risk site ${ }^{16}$. It is an expected result that this risk will increase with deeper OF and longer LL. With our results, it could be said that individuals with hypoplasia or aplasia of FS had less deep OF and short LL. In this context, FSV will be a mark in terms of measurement of skull base depth, especially in patients before the skull base surgery. Since there is a relation between PMS and FSV according to the results of the current study, the anatomical variants and the OFD should be evaluated.

\section{Study Limitations}

One of our study's limitations is the retrospective style. Since the deep OF is undesirable anatomy for skull base surgery due to possible complications, it is important to understand these anatomical details. However, we did not evaluate the possible complications with these anatomical differences, which could be another limitation of the study. Further prospective studies with larger series that evaluated this point would provide a more reliable perspective.

\section{CONCLUSIONS}

The presence of PMS may reflect the development and volume of the frontal sinus. With the presence of PMS, a smaller FS, shorter LL, and less deep OF may be expected. The imaging information of these anatomical variants may have an influence on avoiding surgical complications.

Published in: The preliminary findings of this study presented in the Turkish Society of Neuroradiology, 29 ${ }^{\text {th }}$ Year Annual Meeting with International Participation, on February 14-16, 2020, Istanbul, Turkey. The scientific abstract was published on the relevant issue of Neuroradiology, the official journal of the Turkish Society of Neuroradiology.

\section{Ethics}

Ethics Committee Approval: Istanbul Medeniyet University Goztepe Training and Research Hospital Clinical Research Ethics Committee approved this retrospective case-control study (decision no: 2019/0133, date: 27.03.2019). 
Informed Consent: Since it is retrospective, written informed consent was waived.

Peer-review: Externally and internally peer-reviewed.

\section{Author Contributions}

Concept: B.A., M.B.E., Design: B.A., M.B.E., Data Collection and/or Processing: B.A., M.B.E., Analysis and/or Interpretation: B.A., M.B.E., Writing: B.A., M.B.E.

Conflict of Interest: The authors have no conflict of interest to declare.

Financial Disclosure: The authors declared that this study has received no financial support.

\section{REFERENCES}

1. Zdilla MJ, Russell ML, Koons AW, Bliss KN, Mangus KR. Metopism: a study of the persistent metopic suture. J Craniofac Surg. 2018;29:2048.

2. Nikolova S, Toneva D, Georgiev I, Lazarov N. Digital radiomorphometric analysis of the frontal sinus and assessment of the relation between persistent metopic suture and frontal sinus development. Am J Phys Anthropol. 2018;165:492-506.

3. Bademci G, Kendi T, Agalar F. Persistent metopic suture can mimic the skull fractures in the emergency setting? Neurocirugia (Astur). 2007;18:238-40.

4. Babu AC, Nair MRPB, Kuriakose AM. Olfactory fossa depth: CT analysis of 1200 patients. Indian J Radiol Imaging. 2018;28:395-400.

5. Çomoğlu Ş, Şahin B, Sönmez S, Değer K. Frontal sinus pneumatization affects height of the lateral lamella and position of anterior ethmoidal artery. J Craniofac Surg. 2017;28:265-9.

6. Kayabasi S, Hizli O, Ozkan D. Does paranasal sinus development affect olfactory fossa depth and lateral lamella length? Laryngoscope. 2019:129:2458-63.

7. Keros P. [On the practical value of differences in the level of the lamina cribrosa of the ethmoid]. Z Laryngol Rhinol Otol. 1962;41:80913. (German)
8. Von Elm E, Altman DG, Egger M, et al. Strengthening the reporting of observational studies in epidemiology (STROBE) statement: guidelines for reporting observational studies. BMJ 2007 Oct 20;335:806-8.

9. Guerram A, Le Minor JM, Renger S, Bierry G. Brief communication: the size of the human frontal sinuses in adults presenting complete persistence of the metopic suture. Am J Phys Anthropol. 2014;154:6217.

10. Khamanarong K, Tuamsuk P, Woraputtaporn W, et al. Incidencia de metopismo en cráneos Tailandeses adultos. Int J Morphol. 2015;33:514.

11. Baaten PJ, Haddad M, Abi-Nader K, Abi-Ghosn A, Al-Kutoubi A, Jurjus AR. Incidence of metopism in the Lebanese population. Clin Anat. 2003;16:148-51.

12. Bilgin S, Kantarcı UH, Duymus M, et al. Association between frontal sinus development and persistent metopic suture. Folia Morphol (Warsz). 2013;72:306-10.

13. Gumus C, Yildirim A. Radiological correlation between pneumatization of frontal sinus and height of fovea ethmoidalis. Am J Rhinol. 2007;21:626-8

14. Agam MS, Wedemeyer MA, Wrobel B, Weiss MH, Carmichael JD, Zada G. Complications associated with microscopic and endoscopic transsphenoidal pituitary surgery: experience of 1153 consecutive cases treated at a single tertiary care pituitary center. J Neurosurg. 2018:1-8.

15. Krings JG, Kallogieri D, Wineland A, Nepple KG, Piccirillo JF, Getz AE. Complications of primary and revision functional endoscopic sinus surgery for chronic rhinosinusitis. Laryngoscope. 2014;124:838-45.

16. Gera R, Mozzanica F, Karligkiotis A, et al. Lateral lamella of the cribriform plate, a keystone landmark: proposal for a novel classification system. Rhinology. 2018;56:65-72.

17. Ozgursoy OB, Comert A, Yorulmaz I, Tekdemir I, Elhan A, Kucuk B. Hidden unilateral agenesis of the frontal sinus: human cadaver study of a potential surgical pitfall. Am J Otolaryngol. 2010;31:231-4.

18. Sjogren PP, Waghela R, Ashby S, Wiggins RH, Orlandi RR, Alt JA International Frontal Sinus Anatomy Classification and anatomic predictors of low-lying anterior ethmoidal arteries. Am J Rhinol Allergy. 2017;31:174-6. 